\title{
ETHICAL ISSUES AND VALUES IN PHARMACY PRACTICE
}

\author{
DUSANKA KRAJNOVIC $^{1 *}$, TATJANA CRNJANSKI ${ }^{2}$, SAVIC MIRKO $^{3}$ \\ ${ }^{I}$ Department for Social Pharm. and Pharm. Legislation, Faculty of Pharmacy, Belgrade University, 450 Vojvode Stepe, \\ 11221, Belgrade, Serbia \\ ${ }^{2}$ Subotica Pharmacy, 26 Matije Gupca, 24000, Subotica, Serbia \\ ${ }^{3}$ Department of Business Informatics and Quantitative Methods, Faculty of Economics in Subotica, University of Novi Sad, \\ Serbia
}

*corresponding author: dusica.krajnovic@ pharmacy.bg.ac.rs

Manuscript received: June 2020

\begin{abstract}
During their work, pharmacists are faced with a number of ethically difficult situations which include consideration of the values, rights and responsibilities. The overall aim of this study was to analyse the factors that influence the ethical values of pharmacists. We aimed to determine the relationship of these factors and the pharmacists' perceptions of difficulty and frequency of ethical issues in community pharmacy settings. The research design was cross-sectional and descriptive; the data were gathered from a sample of community pharmacists in Serbia by using validated self-administered survey instrument. In all, 590 pharmacists participated (94.06\% females) with working experience from 1 to 39 years (mean $15.17 \pm 10.04$ years). The majority of respondents stated that the main factor influencing the ethical values of pharmacists is professional ethics, followed by family norms. The most common reasons for addressing ethical issues associated with values are related to the following: importance of cooperation with other healthcare professionals, respect for the rules and regulations, patients` wellbeing, working within one's competence to limit liability, controlling and monitoring the organizational and occupational framework of pharmacy profession. The respondents in our study identified an ethical imperative for pharmacists in limiting harm to patients and resistance to commercial pressures which might compromise their judgment. The results demonstrate a need for careful examination of the values that could be identified and explored in dilemmas created by commercial environment and dual personality of users (patients, costumers) of community pharmacy service.
\end{abstract}

\section{Rezumat}

Pe parcursul activității profesionale, farmaciștii se confruntă cu multe situații dificile din punct de vedere etic, ceea ce presupune o analiză a valorilor, drepturilor și responsabilităților. Scopul principal al acestui studiu a fost analiza factorilor care au un impact deosebit asupra valorilor etice ale farmaciștilor. În al doilea rând, cercetarea vizează raporturile dintre acești factori, precum perceperea dificultăţilor aparente și frecvența dezvoltării problemelor legate de aspectele etice în farmacia comunitară. Design-ul studiului a fost trasversal (cross-sectional) și descriptiv; datele au fost colectate din eșantionul farmaciilor comunitare din Serbia prin folosirea instrumentului validat privind automedicația. Studiul a inclus 590 farmacişti (94,06\% femei), cu experiență în activitatea profesională de un an până la treizeci de ani (în medie $15,17 \pm 10,04$ ). Majoritatea respondenţilor au afirmat că factorii principali care influențează valorile etice ale farmaciştilor sunt etica profesională și valorile etice familiale. Cele mai importante motive pentru evidențierea problemelor etice, asociate unui set de valori, sunt legate de: importanţa relaţionării cu alte cadre medicale, respectarea normelor și prevederilor profesionale, bunăstarea pacientului, exercitarea activitătii în vederea limitării numărului de persoane cu răspundere și controlul și monitorizarea cadrului organizator și profesional al profesiei farmaceutice. Respondenții au recunoscut că trebuie să existe un imperativ etic cu scopul de a limita prejudicierea pacientului, din cauza presiunilor comerciale care ar putea compromite judecata profesională. Aceste rezultate indică faptul că există o necesitate de examinare profundă a valorilor care ar putea să fie recunoscute şi explorate în cadrul dilemelor create de anturajul comercial și de dualitatea personalității utilizatorilor de servicii în farmacia comunitară (pacienți, consumatori).

Keywords: ethical values, ethical issues, ethics, community pharmacy

\section{Introduction}

Ethical conduct is very important to every profession and pharmacy is no exception. Work performed by pharmacists could have a direct impact on health, safety and welfare of patients and the ethics is an important aspect in the work of pharmacists. Pharmacists today face many ethically difficult situations [26] when it is necessary to decide what is the right and the wrong way to act. The ethical decision-making in pharmaceutical care is associated with many issues such as: drug dispensing, violation of rules and regulations, resource allocation, communication with patients or customers and teamwork with other health care professionals $[1,3,7,11,18]$. Conflicts arising from the collision of business pressures and professional paternalism and from dual personality of clients as patients and consumers are already well researched and explained [29]. Ethical issues may occur between pharmacists and patients/costumers, pharmacists and physicians, 
among pharmacists, because the values, sense of justice and fairness of each party may differ $[29,36]$. Also, ethical issues can lead a system of morality and ethical principles in conflict and many situations which include an ethical issue also include consideration of the values, rights and responsibilities [2, 4, 9, 32]. The values represent "an enduring belief that a specific mode of conduct or end-state of existence is personally or socially preferable to an opposite or converse mode of conduct or end-state of existence" [34]. On the individual level, the values refer to the criteria and standards that people use in assessing their own and those of other people activities [34, 35].

Values encompass many other objectives already embraced by the healthcare, such as: quality, safety, focus on patients, cost containment and their integration. Kruijtbosch et al. [27] suggested the following values as foundational to pharmacy practice as well as any other healthcare practice: self-determination, compassion, justice, respect for persons, commitment to integrity and ethical practice and commitment to excellence $[27,33]$.Values could be important for the study of pharmacists' behaviour because they could help us understand attitudes, perceptions and motivations. Also, perception of ethical issues could be affected by the values of pharmacists. Finding a solution which directly affects the rights and the well-being of other people is often easier in theory than in practice. A pharmacist must be morally sensitive to recognize and distinguish ethically difficult situations and decide between right and wrong in accordance with the ethical values. The ethics can be influenced by an individual's family values, educational background, social learning, professional activities, beliefs, religious and individual needs $[5,30]$.

This paper aimed to extend previous research of ethical issues in pharmacy practice through the study of pharmacists' values and it is a part of a larger project intended to explore ethical issues in a community pharmacy setting [10].

It was the overall aim of this study to analyse factors influencing ethical values of pharmacists and the reasons for compromising ethical values. Secondary aim is to determine the correlation of these factors to pharmacists' perceptions of difficulty and frequency of ethical issues in community pharmacy setting.

\section{Materials and Methods}

A quantitative cross-sectional multicentre study was performed on a convenient sample of community pharmacists with an original and validated selfadministered survey instrument. The study was conducted in 23 community pharmacy chains, which were selected randomly from different parts of Serbia. The survey instrument had been developed and validated originally [12] as a two part 16-items self-administered survey instrument - EISP scale (the Ethical Issue Scale for
Community Pharmacy Setting). This instrument is of good reliability, proven by Cronbach's $\alpha$ coefficient [13] which was 0.83 in the first part and 0.84 in the second one. It demonstrates high degree of test-retest reliability (for the part that examines difficulty ICC = 0.809 , for the part that examines frequency ICC $=$ 0.929 ) as well as content, criterion, and construct validity $[10,12]$.

The two parts of the EISP scale have two identical set of 16 ethical items that the pharmacists encountered in a community pharmacy setting. Sixteen ethical issues are associated with the confidentiality, patients' autonomy, non-malfeasance, beneficence, justice and informed consent. One part of the EISP is used to assess the difficulty, and the other part with the same set of 16 statements is used to assess the frequency of ethical issues. The instrument also includes questions about socio-demographic characteristics of respondents and questions about factors influencing ethical values of pharmacists. We also assessed the reasons for compromising by asking pharmacists to identify them. Ethics approval was obtained from the Pharmaceutical Chamber of Serbia Ethics Committee.

This instrument with an Invitation Letter and a Consent Form were sent out to all licensed pharmacists employed in the selected community pharmacies. All pharmacists signed an informed consent before the participation. Frequency of occurrence of each proposed ethical issue faced by community pharmacist was assessed by the scale of one to five $(1=$ does not occur, $5=$ always occurs). The respondents were also asked on a scale of one to five ( 1 = not difficult, 5 = extremely difficult), to rank their perceptions regarding the extent to which they considered the various issues to be of ethical importance in their community settings. The purpose of these statements was to find out how often certain problems occurred in pharmacy practice and how pharmacists dealt with these problems or, if they had not encountered such problems, how they thought they would deal with them. Mean values of difficulty and frequency of ethical problems of pharmacists were compared using ANOVA test as parametric statistical approach, across different groups of factors that influence pharmacists' values (family, religion, professional ethics, working experience, empathy, ethical education and discussion with colleagues).

\section{Statistical analysis}

The data analysis also included descriptive statistics and correlation analysis. In the cases of statistically significant differences between group' factors that influence pharmacists' values on the basis of ANOVA results, we have conducted two post-hoc tests: Tukey and LSD test. The statistical analyses were performed using the SPSS (Statistical Package for Social Sciences ver. 22). Level of significance for all statistical tests was set $a$ priori at $\mathrm{p}<0.05$. 


\section{Results and Discussion}

Eight hundred seventy nine (879) pharmacists across Serbia were recruited to participate in a survey and have received by mail a survey scale - EISP with an Invitation Letter and a Consent form. Overall, 735 participants returned filled survey scale (response rate $=$ $83.62 \%$ ). The results of the 690 completely filled out scales (completeness rate $=78.49 \%$ ) were analysed. The majority of the respondents were female $(94.06 \%)$ which corresponds with current demographics of community pharmacists in Serbia. The mean age of the respondents was $42.36 \pm 9.45$ years (ranging from 24 to 64 years) and the average years of practice for all the participants were $15.17 \pm 10.04$ years (from one to 39 years of work experience). The demographic characteristics of pharmacists are fully described and reported in a previous paper [10].

An overview of the respondents' perception about factors that influence pharmacists' ethical values is presented in Table I.

Almost $85 \%$ of participants identified family norms (family upbringing) and professional ethics as most important in the forming of their ethical values. It is interesting that a small percentage of participants stated that their ethical values were influenced by the religion, discussion with a colleague and additional courses in ethics. Responses about the reasons that scare pharmacists about compromising their ethical values are shown in Table II.

Table I

Factors influencing ethical values of pharmacists

\begin{tabular}{|l|c|c|}
\hline \multicolumn{1}{|c|}{ Factor } & Number of pharmacists (N) & Percentage (\%) \\
\hline Family norms & 190 & 27.54 \\
\hline Religion & 7 & 1.01 \\
\hline Professional code of ethics & 396 & 57.39 \\
\hline Work experience & 40 & 5.80 \\
\hline Empathy towards patients & 39 & 5.65 \\
\hline Ethics education & 8 & 1.16 \\
\hline Discussion with colleagues about ethical issues & 10 & 1.45 \\
\hline Total & 690 & 100.00 \\
\hline
\end{tabular}

Table II

Factors that make uncomfortable respondents about compromising ethical values

\begin{tabular}{|l|c|c|}
\hline & Number of pharmacists (N) & Percent (\%) \\
\hline That my supervisor will find out & 4 & 0.58 \\
\hline That I'll have legal problems & 85 & 12.32 \\
\hline That I'll harm a patient & 425 & 61.59 \\
\hline That I'll compromise my competence & 176 & 25.51 \\
\hline Total & 690 & 100.00 \\
\hline
\end{tabular}

Table III

Proposed situations with ethical issues

Ethical issue

1 A pharmacist is prevented from dispensing a medicine to the patient due to an administrative error in the prescription

2 A pharmacist dispenses a medicine he/she personally considers inadequate for the therapeutic treatment of the patient, in order to avoid any conflicts with the physician

3 A patient can't afford the necessary medicine

4 A prescription of the patient can't be filled, due to legal constraints e.g. inadequate diagnosis, the findings of medical review board etc.

5 A pharmacist dispenses a generic drug instead of an original branded medicine

6 A pharmacist has to dispense a drug therapy which he/she believes will not be beneficial to the patient

7 A patient is unable to understand health information and advice provided by the pharmacist

8 A pharmacist is facing a clearly expressed mistrust of the patient in the prescribed therapy and is required to act on that

9 A pharmacist performs several tasks simultaneously, while providing pharmaceutical services to a patient

10 A pharmacist needs to provide confidential information to the patient when the patient's privacy is compromised by the presence of other patients

11 A pharmacist is considering violating the rules and regulations in order to perform an act of humanity

12 A pharmacist is under pressure to achieve daily sales targets for the pharmacy

13 A pharmacist needs to inform a patient of the reasons for the prescribed therapy, since the patient doesn't know his/her diagnosis (irrespective of the reason). The patient may inquire e.g.: "Why do I need to take this drug?" etc.

14 A pharmacist is selling a falsely advertised dietary supplement

$\mathbf{1 5}$ It is necessary to call into question the competence of a colleague for the sake of the patient's well-being

16 It is necessary to call into question his/her own competence for the sake of the patient's well-being 
FARMACIA, 2021, Vol. 69, 2

Tables IV and V summarized the results showing the association between different factors influencing ethical values of pharmacists and pharmacists' perceptions of difficulty, and the frequency of 16 proposed situations with ethical issues listed by Table III. As shown in Table IV, there are differences among how pharmacists perceived the difficulty of certain ethical questions in practice, based on the factor they reported that influences their values.

We have noticed that based on seven factors influencing ethical values, pharmacists perceived difficulty significantly different in three situations with ethical issues ( $\mathrm{p}<$ 0.05 ), on the basis of ANOVA test results presented in the Table IV.

Table IV

Difference between factors influencing ethical values of pharmacists in relation to pharmacists' perceptions of difficulty 16 proposed ethical issues (ANOVA results)

\begin{tabular}{|c|c|c|c|c|c|c|c|c|}
\hline Factors & $\begin{array}{c}\text { Family } \\
\text { norms }\end{array}$ & Religion & $\begin{array}{c}\text { Professional } \\
\text { ethics }\end{array}$ & $\begin{array}{c}\text { Working } \\
\text { experience }\end{array}$ & $\begin{array}{c}\text { Empathy } \\
\text { towards } \\
\text { patients }\end{array}$ & $\begin{array}{c}\text { Ethics } \\
\text { education }\end{array}$ & $\begin{array}{c}\text { Discussion } \\
\text { with } \\
\text { colleagues }\end{array}$ & $\begin{array}{c}\text { Statistical } \\
\text { significance }\end{array}$ \\
\hline $\begin{array}{c}\text { Ethical } \\
\text { issues }\end{array}$ & Mean \pm SD & Mean \pm SD & Mean \pm SD & Mean \pm SD & Mean \pm SD & Mean \pm SD & Mean \pm SD & p-value \\
\hline 1 & $3.04 \pm 1.16$ & $3.57 \pm 1.40$ & $3.08 \pm 1.09$ & $2.93 \pm 1.14$ & $3.21 \pm 1.26$ & $3.25 \pm 1.28$ & $3.20 \pm 1.40$ & 0.793 \\
\hline 2 & $3.90 \pm 1.13$ & $3.57 \pm 1.81$ & $4.15 \pm 0.99$ & $3.53 \pm 1.32$ & $3.85 \pm 1.07$ & $4.00 \pm 1.41$ & $3.70 \pm 1.41$ & $\mathbf{0 . 0 0 4 *}$ \\
\hline 3 & $3,75 \pm 1.18$ & $4.29 \pm 1.50$ & $3.61 \pm 1.04$ & $3.60 \pm 1.19$ & $3.79 \pm 0.95$ & $3.38 \pm 1.06$ & $3.70 \pm 1.25$ & 0.48 \\
\hline 4 & $3.65 \pm 1.10$ & $3.71 \pm 1.11$ & $3.58 \pm 1.04$ & $3.55 \pm 1.17$ & $4.03 \pm 0.99$ & $3.63 \pm 1.40$ & $3.50 \pm 1.08$ & 0.359 \\
\hline 5 & $2.81 \pm 1.10$ & $2.14 \pm 0.90$ & $2.89 \pm 1.13$ & $2.60 \pm 0.67$ & $2.62 \pm 1.14$ & $2.38 \pm 0.52$ & $3.10 \pm 0.88$ & 0.161 \\
\hline 6 & $3.86 \pm 1.09$ & $3.29 \pm 0.95$ & $3.80 \pm 1.03$ & $3.63 \pm 1.03$ & $3.64 \pm 0.96$ & $3.63 \pm 1.19$ & $4.00 \pm 0.67$ & 0.559 \\
\hline 7 & $3.55 \pm 1.06$ & $3.00 \pm 1.41$ & $3.71 \pm 1.03$ & $3.68 \pm 1.10$ & $3.87 \pm 0.99$ & $3.50 \pm 1.07$ & $4.20 \pm 0.63$ & 0.111 \\
\hline 8 & $3.07 \pm 1.06$ & $2.86 \pm 1.21$ & $3.21 \pm 1.01$ & $3.10 \pm 1.11$ & $3.28 \pm 1.28$ & $3.50 \pm 1.07$ & $3.90 \pm 0.74$ & 0.163 \\
\hline 9 & $3.52 \pm 1.07$ & $3.00 \pm 1.16$ & $3.49 \pm 1.11$ & $3.43 \pm 1.04$ & $3.67 \pm 1.01$ & $3.13 \pm 0.64$ & $4.20 \pm 0.79$ & 0.256 \\
\hline 10 & $3.52 \pm 1.08$ & $3.00 \pm 1.16$ & $3.59 \pm 1.08$ & $3.58 \pm 1.11$ & $3.54 \pm 1.07$ & $3.50 \pm 1.20$ & $3.80 \pm 0.92$ & 0.812 \\
\hline 11 & $3.93 \pm 1.19$ & $3.29 \pm 1.38$ & $4.11 \pm 0.99$ & $3.80 \pm 1.11$ & $3.72 \pm 1.26$ & $3.63 \pm 1.06$ & $3.90 \pm 1.45$ & $\mathbf{0 . 0 4 6} *$ \\
\hline 12 & $3.52 \pm 1.29$ & $3.43 \pm 1.51$ & $3.55 \pm 1.18$ & $3.45 \pm 1.24$ & $3.74 \pm 1.21$ & $3.25 \pm 1.49$ & $3.50 \pm 1.43$ & 0.927 \\
\hline 13 & $3.13 \pm 1.13$ & $2.86 \pm 1.46$ & $3.35 \pm 1.08$ & $3.20 \pm 1.14$ & $2.95 \pm 1.05$ & $3.13 \pm 0.64$ & $3.30 \pm 1.06$ & 0.141 \\
\hline 14 & $3.01 \pm 1.17$ & $2.29 \pm 0.76$ & $2.94 \pm 1.16$ & $3.13 \pm 1.16$ & $2.69 \pm 1.10$ & $2.75 \pm 0.89$ & $2.60 \pm 0.97$ & 0.337 \\
\hline 15 & $3.65 \pm 1.20$ & $3.14 \pm 1.22$ & $3.73 \pm 1.02$ & $3.65 \pm 1.15$ & $3.46 \pm 1.05$ & $3.63 \pm 1.19$ & $3.40 \pm 1.17$ & 0.559 \\
\hline 16 & $3.49 \pm 1.30$ & $2.43 \pm 1.27$ & $3.54 \pm 1.15$ & $3.43 \pm 1.32$ & $3.00 \pm 1.26$ & $3.88 \pm 0.99$ & $3.60 \pm 1.27$ & $\mathbf{0 . 0 3 9 *}$ \\
\hline
\end{tabular}

Bold denotes significance threshold of * $\mathrm{p}<0.05$

Table V

Difference between the views on how frequent the 16 proposed ethical situations are in relation to factors influencing ethical values of pharmacists (ANOVA results)

\begin{tabular}{|c|c|c|c|c|c|c|c|c|}
\hline Factors & $\begin{array}{c}\text { Family } \\
\text { norms }\end{array}$ & Religion & $\begin{array}{c}\text { Professional } \\
\text { ethics }\end{array}$ & $\begin{array}{c}\text { Working } \\
\text { experience }\end{array}$ & $\begin{array}{c}\text { Empathy } \\
\text { towards } \\
\text { patients }\end{array}$ & $\begin{array}{c}\text { Ethics } \\
\text { education }\end{array}$ & $\begin{array}{c}\text { Discussion } \\
\text { with } \\
\text { colleagues }\end{array}$ & $\begin{array}{c}\text { Statistical } \\
\text { significance }\end{array}$ \\
\hline $\begin{array}{c}\text { Ethical } \\
\text { issues }\end{array}$ & Mean \pm SD & Mean \pm SD & Mean \pm SD & Mean \pm SD & Mean \pm SD & Mean \pm SD & Mean \pm SD & p- value \\
\hline 1 & $3.87 \pm 1.29$ & $3.43 \pm 1.51$ & $3.87 \pm 1.23$ & $3.55 \pm 1.18$ & $3.82 \pm 1.23$ & $3.38 \pm 1.41$ & $3.90 \pm 1.29$ & 0.599 \\
\hline 2 & $2.22 \pm 1.11$ & $1.86 \pm 1.07$ & $2.07 \pm 0.94$ & $1.85 \pm 0.74$ & $2.15 \pm 0.96$ & $1.75 \pm 0.71$ & $1.90 \pm 0.99$ & 0.277 \\
\hline 3 & $3.75 \pm 1.20$ & $3.57 \pm 1.62$ & $3.74 \pm 1.10$ & $3.40 \pm 1.09$ & $4.05 \pm 1.15$ & $3.25 \pm 1.17$ & $3.30 \pm 1.06$ & 0.220 \\
\hline 4 & $3.55 \pm 1.17$ & $3.43 \pm 1.51$ & $3.44 \pm 1.13$ & $3.23 \pm 1.12$ & $3.59 \pm 1.27$ & $2.75 \pm 071$ & $3.10 \pm 1.29$ & 0.277 \\
\hline 5 & $2.90 \pm 1.33$ & $2.86 \pm 1.07$ & $2.71 \pm 1.28$ & $2.48 \pm 0.96$ & $2.67 \pm 1.28$ & $2.50 \pm 0.77$ & $2.80 \pm 1.48$ & 0.507 \\
\hline 6 & $2 . .11 \pm 0.88$ & $2.29 \pm 0.95$ & $2.09 \pm 0.84$ & $2.10 \pm 0.71$ & $2.05 \pm 0.83$ & $1.75 \pm 0.71$ & $2.10 \pm 0.74$ & 0.930 \\
\hline 7 & $2.53 \pm 1.04$ & $2.00 \pm 0.58$ & $2.58 \pm 1.02$ & $2.38 \pm 0.87$ & $2.67 \pm 1.20$ & $2.38 \pm 0.92$ & $2.70 \pm 0.82$ & 0.603 \\
\hline 8 & $2.41 \pm 0.87$ & $2.14 \pm 0.69$ & $2.48 \pm 0.92$ & $2.18 \pm 0.55$ & $2.67 \pm 1.20$ & $2.75 \pm 1.04$ & $2.30 \pm 095$ & 0.203 \\
\hline 9 & $3.21 \pm 1.38$ & $2.29 \pm 1.13$ & $3.05 \pm 1.32$ & $2.53 \pm 1.11$ & $3.23 \pm 1.27$ & $2.63 \pm 1.41$ & $3.30 \pm 1.34$ & $\mathbf{0 . 0 4 3}$ \\
\hline 10 & $2.86 \pm 1.23$ & $2.57 \pm 1.27$ & $2.79 \pm 1.17$ & $2.35 \pm 0.95$ & $3.08 \pm 1.22$ & $2.75 \pm 1.04$ & $2.20 \pm 0.79$ & 0.076 \\
\hline 11 & $1.97 \pm 1.02$ & $2.86 \pm 1.35$ & $1.97 \pm 1.01$ & $1.70 \pm 0.56$ & $2.21 \pm 1.11$ & $2.00 \pm 1.31$ & $1.60 \pm 0.97$ & 0.608 \\
\hline 12 & $2.52 \pm 1.26$ & $2.43 \pm 1.27$ & $2.31 \pm 1.18$ & $2.28 \pm 0.99$ & $2.79 \pm 0.42$ & $2.50 \pm 1.51$ & $2.50 \pm 1.32$ & 0.176 \\
\hline 13 & $2.26 \pm 0.85$ & $1.86 \pm 0.69$ & $2.22 \pm 0.77$ & $2.23 \pm 0.80$ & $2.28 \pm 0.97$ & $2.25 \pm 0.46$ & $1.90 \pm 0.74$ & 0.714 \\
\hline 14 & $2.67 \pm 1.4$ & $2.57 \pm 0.98$ & $2.71 \pm 1.07$ & $2.63 \pm 1.10$ & $2.69 \pm 1.00$ & $2.63 \pm 1.30$ & $2.70 \pm 1.25$ & 0.999 \\
\hline 15 & $1.85 \pm 0.72$ & $1.86 \pm 0.69$ & $1.86 \pm 0.69$ & $1.75 \pm 0.59$ & $2.15 \pm 0.81$ & $1.50 \pm 0.54$ & $1.50 \pm 0.71$ & $\mathbf{0 . 0 4 9 *}$ \\
\hline 16 & $1.85 \pm 0.81$ & $1.86 \pm 0.69$ & $1.82 \pm 0.83$ & $1.70 \pm 0.56$ & $1.90 \pm 0.50$ & $1.38 \pm 0.52$ & $1.70 \pm 0.82$ & 0.541 \\
\hline
\end{tabular}


FARMACIA, 2021, Vol. 69, 2

Post-hoc analysis (Tukey test) for ethical Issue 2: "A pharmacist dispenses a medicine he/she personally considers inadequate for the therapeutic treatment of the patient, in order to avoid any conflicts with the physician" showed high statistically significant differences between mean values of the groups answered that professional ethics is the most influential factor on their ethical values and the group answered that most influential factor on their ethical values is working experience $(p$-value $=0.009)$.

Post-hoc Tukey test showed no statistically significant difference in issue considering violating the rules and regulations in order to perform an act of humanity and issue of working within one's competence for patient's well-being. We have decided to use post-hoc LSD test, which showed significant differences $(p<0.05)$ related to groups of respondents answered that religion and ethics courses are the most influential factors on pharmacists' values. Differences between results of two post-hoc tests can be explained by the size of the groups, because only 7 respondents declared religion as influential factor, and only 8 respondents considered that Course in Ethics is an important factor, this is why Tukey test was not able to discover statistically significant differences between groups.

Responses in the second part of the EISP scale (Table V) showed that based on the most influential factor for developing values, pharmacists' groups differ significantly in only two situations (issues 9 and 15) when reported the frequency of arising for certain ethical issues in practice $(\mathrm{p}<0.05)$.

Post-hoc Tukey test showed no statistically significant difference in Issue 9: "A pharmacist performs several tasks simultaneously, while providing pharmaceutical services to a patient" and Issue 15: "It is necessary to call into question the competence of a colleague for the sake of the patient's well-being". Post hoc LSD test showed significant differences $(\mathrm{p}<0.05)$ related to groups of respondents answered that Religion and Course in ethics are the most influential factors for pharmacist's values. Once again, very few pharmacists declared that religion and corse in ethics are the most influential factors on their values.

There is high statistically significant differences between age groups of respondents related to the most influential factor on their ethical values $(\mathrm{p}=0.033)$. The results showed that none of the participants aged between 20 and 29 years reported work experience as the most influential factor, and professional ethics is the most important factor in all age groups. Also, there were high statistically significant differences between groups with different years of working experience $(p=0.005)$. None of respondents with working experience between 5 and 15 years of practice reported religion as the most influential factor, and religion is the least cited factor in all groups (also shown in Table I).

There are no statistically significant differences between age groups of respondents and groups with different years of working experience related to factors that scare them about compromising ethical values $(\mathrm{p}=$ $0.168,0.847$, respectively).

To our knowledge, no study has directly examined factors influencing pharmacists` ethical values and the reasons for compromising ethical values at retail pharmacies in Serbia. The Pharmacy profession moves towards embracing the pharmaceutical care and becoming a more patient-centred profession; it also places new demands on and expectations from pharmacists in ethical decision making. As Benson et al. explained in their discussion paper on the pharmacy values, it is "essential to recognize that pharmacy is a "valuebased" as well as a knowledge-based profession" [1]. It is well recognized that personal values play an important role in the ethical decision-making process, in general. In the specific context of healthcare professional behaviour, ethics and values occur as important aspects of the work of pharmacists which is under mounting pressures from drug manufacturers, patients and prescribing physicians. We considered values as ideals sought to be achieved, as well as goals and visions to be realized. If there are no values, pharmacists and other health care workers, would not be able to fulfil their professional aims and duties. Our results can help us to shed light on the factors that pharmacists perceived as most influential on their ethical values as well as how these factors are related to their view on the difficulty and frequency of some ethical issues at the community practice. In addition, the analysis includes factors potentially compromising ethical values.

The results of the research conducted by Haddad showed family as a frequently cited factor (followed by work experience), which the United States pharmacists considered as most influential in their code of ethics [21]. Our findings indicate that majority of respondents' stated professional ethics (followed by family norms) as the main factor influencing their ethical values. That could be explained by the moral development and the morally acceptable behaviour, being taught by immediate families, and shaped by professional ethics and work experiences. Ethics learned at a workplace are a subject of some debates [8]. In addition, some researchers believe that our values are shaped early on. They also believe that we learn the values and ethic from our families, rather than at work [37]. Interestingly, a small percentage of respondents indicated that ethical values are influenced by religion, discusses with colleagues and additional courses in ethics. Also, the findings of Haddad's (1991) study showed that discussions with colleagues and additional courses in ethics have a little impact on the ethical values of pharmacists in the United States [21]. Also, according to research researches conducted in Croatia, the largest percentage of respondents $(83.3 \%)$ stated that they make decisions about ethical issues on their own and more than half of respondents do not feel the need to 
FARMACIA, 2021, Vol. 69, 2

justify their choices with colleagues [38]. According to Haddad [21], religion has a greater impact on the pharmacists` code of ethics. There are numerous studies dealing with the influence of religion on decisionmaking in pharmacy practice [14, 20,24]. It is important to suggest the emerging popularity of medical conscience clauses in the pharmaceutical field. Grady stated that conscience clauses are laws that explicitly allow for health care workers to opt out of certain procedures, usually reproductive and end-of-life therapies, on moral, ethical, or religious grounds [19]. According to him there is neither legislative support nor a rich professional tradition that allows for conscientious objection for health care workers, including pharmacists [19].

However, one of the reasons that a small percentage of respondents in this survey indicated that ethical values are influenced by religion, could be the choice of pharmacy as a profession, which implies putting patients' interests in front of the personal interests of pharmacists. "I think the patient has the right to decide by himself, I cannot decide for him ... I am here to help him to make the right decision", as one of the respondents stated during the interviews, conducted with the aim of generating the EISP. The second reason could be the political background (conventionality and patriarchy, but without impacts of religion) and this requires further research as well as the result that pharmacists up to 15 years of working experience did not identify religion as a factor of influence. But it is understandable that younger pharmacists up to 29 years old did not cite work experience as a factor of influence, since that they are at the beginning of professional work.

Possible reasons, that a small percentage of respondents indicated that their ethical values are influenced by additional courses in ethics, could be an insufficient number of such courses after graduation or inadequate content of such courses (they do not contain examples from practice, which also requires further research). The results of our study showed that the Number 2 Issue, "A pharmacist dispenses a medicine he/she personally considers inadequate for the therapeutic treatment of the patient, in order to avoid any conflicts with the physician" appears statistically significant in the analysis of factors influencing ethical values and pharmacists' perception of difficulty of ethical issues. A post-hoc test showed that the most influential factor on pharmacist's ethical values (for this issue) is the professional ethics.

That may be explained by the fact that professional ethics states the following: (1) the objectives of pharmacists` work are patients` well-being and care for the patients; (2) the safety of patients is important (as one of the basic ethical principle Primum non nocere); (3) respect and cooperation between pharmacists and physicians is very important for improving the therapy outcomes and achieving patients` well-being; (4) the communication with other health care professionals ought to be based on principles of truthfulness, beneficence and respect; (5) relationships and cooperation of health care workers ought to be based on fairness, honesty, respect and the exchange of knowledge and experience; (6) to commit to and focus completely on patients, and not to violate (but follow) the principle of informing a patient.

Health, well-being and safety of patients should be the objective of all healthcare professionals. The inability of healthcare professionals to act upon what they know to be professionally and ethically wrong could be explained by ethical passivity and might lead to harming patients [7]. Consequently, all the disagreements over prescriptions, therapies and opinions lead to conflicts of values [8] and moral distress [24, 25].

In addition, this type of dilemma was common amongst the participants in the study conducted by Chaar $e t$ al. [5]. Results of this study showed that pharmacists need to make "the choice between what is in the best interest of the patient, or ensuring no harm is done to the patient, and what the doctor prescribed", also pharmacists found difficult to choose a course of action [5]. However, the results showed that this ethical issue ("A pharmacist dispenses a medicine he/she personally considers inadequate for the therapeutic treatment of the patient, in order to avoid any conflicts with the physician") indicates unsatisfactory communication between physicians and pharmacists. Lack of cooperation and incomplete understanding between these professions are shown in the results of other studies. Lasselain research shows that General Practitioners (GPs) think that pharmacists do not know anything about diseases [28] and are more reserved about providing information on therapy by pharmacists [31]. In addition, research conducted by Edmunds and Calnan indicates that United Kingdom GPs' showed wariness related to pharmacists' excessive involvement in decisions about what prescribed medicines were appropriate for patients [17]. Other research [23] indicates that pharmacists often think of GPs, as the ones having a negative image of pharmacists as "shopkeepers", and presenting a threat. Results of those studies could explain why such problems occur and point to major barriers for the effective cooperation between doctors and pharmacists. Medicines used in therapy can be highly effective, but at the same time, they could be unsafe. The quality assurance of the pharmacist's actions must therefore be beyond any doubt and represent the essential value of pharmacists` work, as in other health care workers. Why is it so challenging to health care professionals to have good communication and common goals the welfare of patients and the improvement of therapy outcomes? The reasoning and situations (where vanity, self-interest and ethical passivity could prevail over the well-being of patients) require further research. Having a common Code of Ethics for all the health workers might facilitate easier coping with such situations. Responsibility for resolving that sort of ethical problems 
rests with the conscience and individual values of health-care workers for the time being.

Two other statistically significant issues related to factors influencing ethical values and their influence on pharmacists' perception of difficulty of ethical issues are: Issue 11 "A pharmacist is considering violating the rules and regulations in order to perform an act of humanity"; and in Issue 16 "It is necessary to call into question his/her own competence for the sake of the patient's well-being".

Statistically significant issues related to factors influencing ethical values and their influence on pharmacists' perception of frequency of ethical issues are: Issue 9 "A pharmacist performs several tasks simultaneously, while providing pharmaceutical services to a patient" and Issue 15 "It is necessary to call into question the competence of a colleague for the sake of the patient's well-being".

Working with patients, who are in need of help, sometimes can be a source of conflict between the rights and duties, when pharmacists are forced to choose between obeying the law and fulfilling their ethical duty. Rules and regulations must be taken into account in an ethical and value analysis of the pharmacy practice. In many instances, law and ethics coincide, and pharmacists make decisions based on their own ethical values, which are sometimes not in accordance with the law. Synchronizing ethical criteria and regulations is a common problem not only for pharmacists, but for other health care professionals as well. Pharmacists respect the law, but they are ready to violate the law for the welfare of patients. The results of the study conducted by Cooper et al. showed that pharmacists prioritize their own interests and, in particular, the threat of a legal prosecution or a disciplinary action [7]. According to another study, the probability for legal or disciplinary procedures is the leading factor in determining pharmacist's choice of action [6]. The results of Dean`s study suggest that participants are comfortable with rules, and they are keen to act in accordance with them [15].

Results of other studies showed that rules would be broken, if the patient's interests conflicted with the rules [16]; and well-being of patients is more important to pharmacists than the undesirable consequences of violating the law $[11,15]$. Pharmacists lack confidence and feel uncomfortable when dilemmas involve best interests of a patient taking priority over legal requirements [5]. Laws affect all healthcare professionals and can lead to ethical, legal and value conflicts. The results of the research conducted in Croatia showed that pharmacists very often justify their decision to dispense the medicine by arguing that they are acting in the patient's best interest. Responses of participants indicate a conflict between an ethical value, usually the welfare of the patient and legal and procedural matters [38]. Also, $47.2 \%$ of 252 respondents in this study reported that financial or commercial pressures influence their practice based on ethical values [38]. In addition, the safety of a patient must be the priority to all pharmacists, regardless of whether the mistake is made by them or by an incompetent colleague. According to results of our study, a question about pharmacists' competence emerged as a statistically significant one in both cases: in the analysis of factors influencing ethical values, as well as in their impact on difficulty and frequency of ethical issues. Analysing the reasons that pharmacists perceived to be scared about compromising ethical values, the main reasons are: "I will harm a patient" followed by "I will compromise my competence" and "I will have legal problems". That sequence illustrates the value system of pharmacists.

Other ethical issue is related to the organizational and occupational framework of the pharmacy profession. This ethical issue also includes pharmacists' values [38]. Administrative tasks often are the reason for which pharmacists have to prioritize and choose between customers and administrative and care-related tasks. According to other research, the administrative tasks do not allow pharmacists to pay more attention to patients $[5,11]$.

Ethical issues assessed by EISP are associated with values such as: patients` well-being, cooperation with other health care professionals, respect for the rules and regulations, confidentiality and competence. A pharmacist has to be morally motivated and aware that ethical principles have priority over prejudice, economic factors and personal interests, and needs to be morally courageous to apply an ethical decision into practice, although it can lead to conflicts with other healthcare workers. Ethical values of pharmacists may serve as motivating factors for further improvement of pharmaceutical practice, upgrading the communication with other health care professionals and for improving patient outcomes.

Our findings, as reported elsewhere [10], showed that pharmacists prefer to act in accordance with their conscience, in a situation which made them not to obey the rules [10]. It is a matter of concern that in this study approximately one quarter of pharmacists reported that they would violate the code of ethics in order not to compromise themselves. Also, this issue appears as statistically significant in relation to factors influencing ethical values and their influence on pharmacists' perception of difficulty. This requires further research which could even be expanded to follow them into professional practice.

Several limitations have to be acknowledged. Since the study was carried out based on the self-reports and perceptions of respondents, two problems should be taken into account. Perception, compared with facts, can be very time sensitive and what people say about what influenced them and what actually influenced them can be quite different Also, the cross-sectional 
FARMACIA, 2021, Vol. 69, 2

study design does not allow us to establish causal relationships among variables. However, the present work gave us valuable information on factors that shape pharmacists' ethical values and pharmacists' perceptions of the difficulty and frequency of ethical issues. Further studies are necessary to conduct using random sampling and on a larger scale. In particular, it would be interesting to evaluate ethical and moral development of pharmacists`values using a longitudinal method.

\section{Conclusions}

This study demonstrates that professional ethics and family norms have the strongest impact on pharmacists' ethical values and that various factors shape the challenges they face in fulfilling their ethical obligations. The most common reasons for addressing ethical issues associated with values are related to the following: importance of cooperation with other health care professionals, respect for the rules and regulations, patients` well-being, working within one's competence to limit liability and controlling and monitoring the organizational and occupational framework of pharmacy profession.

The main reason that pharmacists perceived to be scared about when compromising ethical values is harming the patients. In addition, personal interests should never be placed above the dignity of others, directly or indirectly involved in a professional relationship. These findings provide insight into how pharmacists perceive their ethical values and their influence on ethical issues in professional work, which could help to fill an empirical gap between the theory and practice in regards to the pharmaceutical ethics. In the future, researchers should focus more heavily on the factors that shape ethical commitments and ethical challenges in pharmaceutical practice.

\section{Acknowledgement}

We want to acknowledge to all community pharmacists who participated for their contribution to this study. At the time of research, the work of DK was partially supported by the framework of a project of Ministry of Education, Science and Technological Development of the Republic of Serbia (project No. 41004). She now receives grant from the Ministry of Education, Science and Technological Development of the Republic of Serbia MPNTR: 451-03-68/2020-14/200161.

\section{Conflict of interest}

The authors declare no conflict of interest.

\section{References}

1. Benson A, Cribb A, Barber N, Understanding pharmacists' values: a qualitative study of ideals and dilemmas in UK pharmacy practice. Soc Sci Med., 2009; 68(12): 2223-2230.
2. Benson $\mathrm{A}, \mathrm{PhD}$ Thesis "Pharmacy values and ethics A qualitative mapping of the perceptions and experiences of UK pharmacy practitioners" King's College, London, 2006.

3. Brock DW, Conscientious refusal by physicians and pharmacists: Who is obligated to do what, and why?. Theor Med Bioeth., 2008; 29(3): 187-200.

4. Brown ME, Ellis S, Linley PA, Booth TG, Professional values and pharmacy practice: implications of a predominantly female Register of Pharmaceutical Chemists. Int J Pharm Pract., 1992; 1(3): 178-183.

5. Ciolan DF, Andrei CL, Mirică A, Toma IE, Drăgănescu D, Rădulescu FȘ, Internships in pharmaceutical students' development. Farmacia 2020; 68(1): 176-184.

6. Cooper RJ, Bissell P, Wingfield J, Dilemmas in dispensing, problems in practice? Ethical issues and law in UK community Pharmacy. Clin Ethics, 2007; 2(2): 103-108.

7. Cooper RJ, Bissell P, Wingfield J, Ethical decisionmaking, passivity and pharmacy. J Med Ethics, 2008; 34(6): 441-445.

8. Cragg W, Teaching Business Ethics: The Role of Ethics in Business and in Business Education. J Bus Ethics, 1997; 16: 231-245.

9. Cribb A, Barber A, Developing Pharmacy Values: Stimulating the Debate - A Discussion Paper. London: Royal Pharmaceutical Society of Great Britain; 2000.

10. Crnjanski T, Krajnovic D, Savic M, Pharmacists' Assessment of the Difficulty and Frequency of Ethical Issues Encountered in Community Pharmacy Settings. Sci Eng Ethics, 2019; 25(4): 1017-1036.

11. Crnjanski T, Krajnovic D, Stojkov-Rudinski S, Tadic I, Ethical dilemmas and moral distress in pharmacy: A qualitative study. HealthMed., 2012; 6(7): 2485-2493.

12. Crnjanski T, Krajnovic D, Tadic I, Stojkov S, Savic M, An Ethical Issue Scale for Community Pharmacy Setting (EISP): Development and Validation. Sci Eng Ethics, 2016; 22: 497-508.

13. Cronbach LJ, Coefficient alpha and the internal structure of tests. Psychometrika, 1951; 16: 297-334.

14. Davidson LA, Pettis CT, Joiner AJ, Daniel M, Cook DM, Klugman CM, Religion and conscientious objection: A survey of pharmacists' willingness to dispense medications. Soc Sci Med., 2010; 71(1): 161-165.

15. Deans Z, Ethical issues in pharmacy practice as discussed by pharmacists. Int J Pharm Pract., 2005; 13(S1): R95.

16. Deans $Z$, The ethics of pharmacy practice: an empirical and philosophical study. PhD Thesis, Keele University, 2008.

17. Edmunds J, Calnan MW, The reprofessionalisation of community pharmacy? An exploration of attitudes to extended roles for community pharmacists amongst pharmacists and General Practitioners in the United Kingdom. Soc Sci Med., 2001; 53(7): 943-955.

18. Fassett WE, Ethics, Law, and the Emergence of Pharmacists' Responsibility for Patient Care. Ann Pharmacother., 2007; 41(7): 1264-1267.

19. Grady A, Legal protection for conscientious objection by health professionals. Virtual Mentor, 2006; 8(5): 327-331.

20. Grealis C, Religion in the Pharmacy: A Balanced Approach to Pharmacists' Right to Refuse to Provide Plan B. Georgetown Law J., 2009; 97(6): 1-7. 
21. Haddad AM, Ethical Problems in Pharmacy Practice: A survey of difficulty and incidence. Am J Pharm Edu., 1991; 55(1): 1-6.

22. Hibbert D, Rees JA, Smith J, Ethical awareness of community pharmacists. Int J Pharm Pract., 2000; 8(2): 82-87.

23. Hughes CM, McCann S, Perceived inter professional barriers between community pharmacists and general practicioners: a qualitative assessment. Br J Gen Pract., 2003; 53(493): 600-606.

24. Kalvemark S, Hoglund AT, Hansson MG, Westerholm P, Arnetz B, Living with conflicts - ethical dilemmas and moral distress in the health care system. Soc Sci Med., 2004; 58(6): 1075-1084.

25. Kalvemark Sporrong S, Hoglund AT, Hansson MG, Westerholm P, Arnetz B, "We are white Coats whirling round" - moral distress in Swedish pharmacies. Pharm World Sci., 2005; 27(3): 223-227.

26. Krajnović D, Jocić D, Milošević Georgiev A. Ethics in modern pharmaceutical practice. Zdravstvena zaštita, 2013; 42(1): 88-100, (available in Serbian).

27. Kruijtbosch M, Gottgens-Jansen W, Floor-Schreudering A, van Leeuwen E, Bouvy ML, Moral dilemmas reflect professional core values of pharmacists in community pharmacy. Int J Pharm Pract., 2019; 27(2): 140-148.

28. Lasselain J, Self-perception of Occupational Roles by Community Pharmacists in the French Health System. J Soc Adm Pharm., 1991; 8: 130-135.

29. Lowenthal W, Ethical dilemmas in pharmacy. J Med Ethics, 1988; 14(1): 31-34.
30. Noordin MI, Ethics in Pharmaceutical Issues. Contemporary Issues in Bioethics. Dr. Peter A. Clark (Ed), In Tech. 2012; 6: 83-102.

31. Ortiz M, Walker W, Thomas R, Physicians - friend or foe? Comparisons between pharmacists' and physicians' perceptions of the pharmacists' role. J Soc Adm Pharm., 1989; 6: 59-68.

32. Porter ME, What is Value in Health Care?. $N$ Eng $J$ Med., 2010; 363(26): 2477-2481.

33. Rider EA, Kurtz S, Slade D, Esterbrook Longmaid $\mathrm{H}^{\text {rd }}$, Ho MJ, Kwok-hung Pun J, Eggins S, Branch WT Jr, The International Charter for Human Values in Healthcare: an interprofessional global collaboration to enhance values and communication in healthcare. Patient Educ Couns., 2014; 96(3): 273-280.

34. Rokeach M, The Nature of Human Values. New York: The Free Press; 1973.

35. Schwartz SH, Universals in the content and structure of values: Theory and empirical tests in 20 countries. In Zanna M. (Ed.). Advances in experimental social psychology. New York: Academic Press; 1992.

36. Stancu E, Tăerel AE, Soroceanu V, Rais C, Ghica M, Ethical aspects of food supplements in EU and Romania. Farmacia, 2019; 67(4): 736-742.

37. Stevens B, "Business Communication and the Ethical Context", in H. Murphy, H. Hildebrandt and J. Thomas (eds.), $7^{\text {th }}$ ed. Effective Business Communication; 1997.

38. Vuković Rodríguez J, Juričić Ž, Perceptions and attitudes of community pharmacists toward professional ethics and ethical dilemmas in the workplace. Res Social Adm Pharm., 2017; 14(5): 1-10. 